\title{
ARTIKELEN
}

\section{Straffen en belonen in detentie}

\section{Een planevaluatie van het Nederlandse systeem van Promoveren en Degraderen*}

Jan Maarten Elbers, Esther van Ginneken, Miranda Boone, Paul Nieuwbeerta \& Hanneke Palmen

Hoewel beloningssystemen in gevangenissen wereldwijd actief zijn, ontbreken evaluaties van de veronderstelde werking van dergelijke systemen. Deze bijdrage reconstrueert de beleidstheorie van zo'n systeem: Promoveren en Degraderen, zoals dat in 2014 in Nederlandse gevangenissen is geïmplementeerd. Met een beleidswetenschappelijke benadering zijn de beoogde doelgroep, middelen, doelen en causale mechanismen van het systeem geïnventariseerd. De beleidstheorie veronderstelt drie middelen, tien doelen en 24 causale mechanismen. Op enkele punten is de beleidstheorie gebrekkig empirisch onderbouwd en houdt zij beperkt rekening met niet-kunners. Deze nauwkeurige reconstructie biedt een uniek inzicht in de veronderstelde werking van een onderdeel van het Nederlandse detentiebeleid en biedt aanknopingspunten voor internationale beschouwingen van gedragsverandering in detentie.

\section{Inleiding}

Jaarlijks stromen gemiddeld 31.000 gedetineerden Nederlandse gevangenissen in en uit (DJI, 2020). In de afgelopen decennia zijn zij 'medeverantwoordelijk' gemaakt voor de invulling en het verloop van hun detentie. Begin jaren negentig werd al geïntroduceerd dat gewenst gedrag in detentie kon worden beloond met extra recreatie, onderwijs en psychosociale hulp. ${ }^{1}$ Begin 2000 was het de bedoeling om deze beloningen te rantsoeneren: enkel geschikte en welwillende gedetineerden moesten er nog voor in aanmerking kunnen komen. ${ }^{2}$ Dat voornemen kreeg in 2008 vaste vorm in het programma Modernisering Gevangeniswezen (MGW). ${ }^{3}$ MGW beoogde om onconventionele gedragspatronen te doorbreken door het dagprogramma in detentie zo in te richten dat het zo veel mogelijk de eigen verantwoordelijkheid voor resocialisatie zou stimuleren (Voortgangsrapportage, 2008). Die responsabilisering van gedetineerden sloot aan bij de maatschappelijke en

* Deze studie is onderdeel van de LIC-studie. De LIC-studie is gefinancierd door de Dienst Justitiële Inrichtingen (DJI) en de Universiteit Leiden. Alle uitspraken, bevindingen en conclusies verwoord in dit artikel zijn afkomstig van de auteurs en geven niet noodzakelijkerwijs die van de DJI weer.

1 Kamerstukken II 1993/94, 22999, nrs. 10 en 11.

2 Kamerstukken II 2005/06, 30300 VI, nr. 147; Kamerstukken II 2007/08, 24587, nr. 236.

3 Kamerstukken II 2007/08, 24578, nr. 299. 
beleidsmatige tendens om burgers te activeren tot meer participatie in de uitvoering van (veiligheids)beleid (Schinkel \& Van Houdt, 2010; Drosterij \& Peeters, 2011). Bovendien zou het enkel investeren in welwillende gedetineerden de gewenste bezuinigingen kunnen realiseren (De Jong e.a., 2016). De herinrichting van het dagprogramma kreeg gestalte in het beleidsprogramma Dagprogramma, Beveiliging en Toezicht op maat (DBT), dat de directe voorloper van het in 2014 geïmplementeerde systeem van Promoveren en Degraderen is. ${ }^{4}$ Dit beloningssysteem heeft gedetineerden uiteindelijk geheel 'zelf verantwoordelijk' gemaakt voor de invulling en het verloop van hun detentie, onder de banier van een persoonsgerichte aanpak. Binnen dit systeem wordt het (on)gewenste gedrag van gedetineerden op systematische wijze beoordeeld, beloond en bestraft.

Wetenschappers en strafrechtjuristen hebben betoogd dat het systeem van Promoveren en Degraderen niet strookt met het resocialisatiebeginsel, omdat de bij ongewenst gedrag te 'verliezen' activiteiten deels resocialisatiedoeleinden dienen (Boone \& Van Hattum, 2014). Naast normatieve kritiek, hebben zij tegengeworpen dat het systeem beperkt aansluit bij heersende criminologische theorieën over succesvolle rehabilitatie van gedetineerden (Boone \& Uit Beijerse, 2018). Tot slot zijn er vraagtekens geplaatst bij de responsiviteit van verminderd zelfredzame gedetineerden in dit systeem (RSJ, 2013a; Kelk, 2015; Van Ginneken, 2018). Er is echter 'nooit een degelijke evaluatie' uitgevoerd van de beleidstheorie of effecten van het systeem van Promoveren en Degraderen (RSJ, 2020, 3).

In deze bijdrage stellen we daarom de volgende onderzoeksvraag centraal: Wat is de beleidstheorie van het systeem van Promoveren en Degraderen zoals dat in 2014 is ingevoerd? Hoewel er na de introductie van het systeem van Promoveren en Degraderen in 2014 nog enkele aanpassingen zijn doorgevoerd, gaat deze bijdrage in op het systeem zoals dat in 2014 is ingevoerd. Deze bijdrage is onderdeel van een dissertatietraject.

Hierna beschrijven we eerst het systeem van Promoveren en Degraderen. Vervolgens bespreken we het theoretische raamwerk van, en eerder onderzoek naar, gedragsbeïnvloedingssystemen in gevangenissen. Daarna lichten we de hier gehanteerde methodiek en het belang van planevaluaties toe. De resultaten worden weergegeven aan de hand van de onderdelen van de beleidstheorie: de beoogde doelgroep, middelen, (sub)doelen en causale veronderstellingen. Aansluitend toetsen we de wetenschappelijke onderbouwing van de meest prominente causale veronderstellingen. In de discussie sluiten we af met een reflectie op de bevindingen en beperkingen van deze evaluatie, en doen we aanbevelingen voor vervolgonderzoek.

4 Stcrt. 2014, 4617. Regeling en Toelichting van de Staatssecretaris van Veiligheid en Justitie van 10 februari 2014 houdende wijziging van de Regeling selectie, plaatsing en overplaatsing van gedetineerden in verband met de invoering van promoveren en degraderen van gedetineerden. 


\section{Het systeem van Promoveren en Degraderen}

Het systeem van Promoveren en Degraderen in Nederlandse gevangenissen beoogt (motivatie voor) gewenst gedrag te belonen met interne en externe vrijheden. ${ }^{5}$ Ongewenst gedrag en gebrek aan motivatie kunnen worden bestraft met (blijvende) ontzegging van die vrijheden. Het systeem kent een Basis- en een Plusprogramma. Het Basisprogramma omvat 43 uur aan activiteiten per week, ${ }^{6}$ waarvan twintig uur arbeid. De overige activiteiten zijn bezoek, geestelijke ondersteuning, luchten, onderwijs, recreatie, sporten, re-integratieactiviteiten en nazorgactiviteiten gericht op huisvesting, inkomen, schulden en zorg. Het Plusprogramma kent 48 uur aan activiteiten per week. Er zijn meer bezoekmogelijkheden en er worden bij het verrichten van arbeid meer vrijheden en verantwoordelijkheden toegekend (zoals werk in groenvoorziening, huisdienst of een baantje als reiniger op de afdeling). Arbeid in het Plusprogramma kan ook beter worden betaald, gepaard gaan met een betere (vak)opleiding en/of van een hoger niveau zijn. ${ }^{7}$ Daarnaast kent dit programma een avond- en een weekendprogramma. In totaal vertoeven Plus-gedetineerden elf uur meer buiten hun cel dan Basis-gedetineerden.

Basis-gedetineerden kunnen promoveren naar het Plusprogramma wanneer zij gewenst gedrag en motivatie tot verandering tonen. ${ }^{8}$ Het Multidisciplinair Overlegorgaan (MDO) beoordeelt eens per zes weken of aan deze twee eisen is voldaan, tenzij er aanleiding is om dit vaker te doen. De vestigingsdirecteur neemt op grond van die beoordeling een besluit tot promotie, degradatie of handhaving (art. 1d Regeling selectie, plaatsing en overplaatsing van gedetineerden (RSPOG)). In de RSPOG (2014) is gewenst gedrag gedefinieerd in concrete gedragsregels (groen gedrag), net als welk gedrag leidt tot handhaving van of degradatie naar het Basisprogramma (rood gedrag). Er bestond tot oktober 2020 ook een oranje (dit-kanbeter) gedragscategorie. Oranje gedrag wordt niet per definitie bestraft met degradatie, maar wel ontmoedigd. Voorbeelden van groen gedrag zijn meewerken aan het dagprogramma en bereid zijn te stoppen met criminaliteit. Oranje (dit-kanbeter) gedrag is onder meer een kort lontje hebben en het niet nemen van verantwoordelijkheid voor eigen gedrag. Voorbeelden van rood gedrag zijn het willens en wetens veroorzaken van stank en vervuiling en fysieke agressie naar anderen. Gedetineerden moeten zogezegd ook motivatie voor verandering tonen om in het Plusprogramma te komen en te blijven. Deze verandering wordt afgelezen uit deelname in de cursussen Reflector en Kies voor Verandering $(\mathrm{KvV})$. Niet deelnemen aan deze cursussen wordt geïnterpreteerd als een gebrek aan motivatie, en bestraft met toewijzing naar het Basisprogramma. ${ }^{9}$ Niet kunnen deelnemen aan de cursus $\mathrm{KvV}$

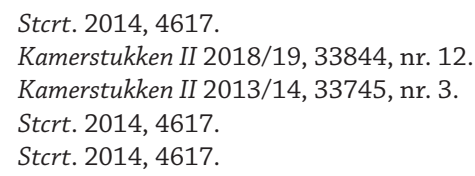


wegens gebrekkige taalvaardigheid is geen reden om gedetineerden toegang tot het Plusprogramma te ontzeggen (Van Gent, 2013). ${ }^{10}$

\section{Contingency Management}

Het systeem van Promoveren en Degraderen is een type Contingency Management (CM)-systeem. Deze gedragsbeïnvloedingssystemen zijn gebaseerd op operante conditioneringstheorie (Spiegler \& Guevremont, 1993). De principes van deze theorie veronderstellen dat gewenst gedrag toeneemt als het systematisch wordt beloond. Dat geldt ook voor het afnemen van ongewenst gedrag door bestraffing (Burdon e.a., 2001). De toepassing van CM-systemen in detentie was vooral populair in de jaren 1950 tot 1970 (zie Gendreau e.a., 2014). In de jaren daarna vielen deze systemen in ongenade bij wetenschappers wegens de beperkte rol die deze systemen toekenden aan cognitie, hetgeen conflicteerde met nieuwe inzichten van de cognitieve gedragswetenschap (Woolredge \& Smith, 2018). Tegenwoordig worden CM-systemen toegepast in gevangenissen in Canada, Engeland en Wales, Nederland, Roemenië en de Verenigde Staten (The Denver Post, 2010; Michigan Department of Corrections, 2019; Serin \& Hanby, 2009; Crewe \& Levins, 2020; The Guardian, 2019; Moriar e.a., 2019; Van Gent, 2013). Beloningen die in CM-systemen in detentie worden gebruikt, zijn vaak materieel (zoals winkelartikelen, geld), sociaal (zoals complimenten, telefoonkaarten, extra bezoekmogelijkheden) en/of betreffen meer tijd voor activiteiten (zoals recreatie of luchten) (Gendreau \& Listwan, 2018). Straffen kunnen, naast het toevoegen van negatieve consequenties (zoals tijd doorbrengen in de isoleercel), ook bestaan uit het wegnemen van positieve consequenties (beloningen), zoals in het systeem van Promoveren en Degraderen.

CM-systemen kunnen op allerlei punten verschillen: de beoogde doelgroep, de omgeving, definities van (on)gewenst gedrag, de selectie en toepassing van beloningen en straffen, evenals de doelen. Historisch gezien werden CM-systemen in detentie toegepast voor twee doeleinden: het stimuleren van regelnaleving, om zo de veiligheid en orde in de inrichting te bewaren, en het afleren van verslavingsgedrag van gedetineerden (Kratcoski, 2017). Voor zover bekend zijn deze systemen niet eerder ingezet onder (niet-verslaafde) gedetineerden op reguliere afdelingen om rehabilitatie in de bredere zin van het begrip (duurzame psychologische verandering) te bevorderen. Sommige onderzoekers dichten CM-systemen echter wel die rehabilitatieve waarde toe (Gendreau \& Listwan, 2018), al is wetenschappelijke evidentie voor die claim niet voorhanden.

10 Met de aanpassing van de RSPOG op 1 oktober 2020 (Kamerstukken II 2017/18, 35122, nr. 6) is de oranje gedragscategorie verdwenen, omdat deze categorie voor onduidelijkheden zorgde bij personeel en gedetineerden zou demotiveren. Ook zijn de gedragscriteria veralgemeniseerd en gereduceerd. Het uitgangspunt blijft het bevorderen van gewenst gedrag door te belonen en het reduceren van ongewenst gedrag door te straffen. Dat suggereert dat het onderliggende theoretische raamwerk, inclusief daarop gestoelde veronderstelde mechanismen, ongewijzigd is gebleven. 


\section{Eerder beleidsonderzoek naar Contingency Management in gevangenissen}

Er is weinig empirisch onderzoek verricht naar CM-systemen die zijn toegepast in reguliere detentiepopulaties. Serin en Hanby (2009) voerden een literatuurreview uit en troffen vijf studies aan. Deze studies geven geen accuraat beeld van de werking van een dergelijk systeem onder gedetineerden. De studies zijn gedateerd (1973-2003), zeer kleinschalig $(\mathrm{N}<10)$ of betroffen onderzoeken naar specifieke doelgroepen, zoals vrouwelijke gedetineerden op afgezonderde afdelingen of in een zeer beveiligde inrichting. De vijf studies betroffen drie effectevaluaties, een procesevaluatie en een planevaluatie. Serin en Hanby (2009) concludeerden op grond van de effectevaluaties dat het bewijs dat CM-systemen regelnaleving in detentie effectief kunnen bevorderen - op zijn best - gemixt is. Die bevinding werpt onder meer de vraag op hoe deze systemen operante conditioneringsprincipes precies toepassen en wanneer gesproken kan worden van effectieve doelbereiking. Een vraag die centraal staat in planevaluaties. De enige door de Canadese onderzoekers aangetroffen planevaluatie behandelde het Britse Incentives and Earned Privileges (IEP)-programma (Bosworth \& Liebling, 1995).

Planevaluaties van CM-systemen toegepast onder reguliere gedetineerdenpopulaties zijn zeldzaam. Ook tien jaar na de review van Serin en Hanby (2009) lijkt de planevaluatie van Bosworth en Liebling (1995) de enige (bij de auteurs bekende) uitzondering. De Britse evaluatoren hebben de middelen, doelen en veronderstelde causale mechanismen van het (nog steeds operationele) Britse IEP-programma onderzocht. Dit programma houdt in dat gedetineerden beloond of gestraft worden op grond van hun gedrag en motivatie. Het programma beoogt onder meer de eigen verantwoordelijkheid van gedetineerden te stimuleren, en de orde en veiligheid in de inrichting te bevorderen. In aanvulling op de twee historische doelstellingen die Kratcoski (2017) onderscheidt, kan dus ook het stimuleren van de eigen verantwoordelijkheid als moderne doelstelling van een $\mathrm{CM}$-systeem in detentie worden aangemerkt. Gehanteerde beloningen zijn onder meer extra bezoeken, beschikbaarheid van televisie op cel en meer tijd uit de cel. De evaluatoren vonden dat Britse beleidsmakers destijds van simplistische aannames over de onderliggende causale veronderstellingen van het programma uitgingen. Zo gingen beleidsmakers er aanvankelijk van uit dat gedetineerden rationele gedragskeuzes maken en de geselecteerde beloningen voldoende aantrekkelijk waren om regelnaleving en recidivereductie na detentie te bevorderen (Khan, 2016; Liebling, 2008), zonder die claims met wetenschappelijk bewijs te staven of empirisch te valideren.

De toegevoegde waarde van planevaluaties is dat zij, door het ontvouwen van de beleidstheorie, inzicht kunnen geven in de manier waarop effecten van (justitiële) interventies mogelijk tot stand zijn gekomen (Donaldson \& Lipsey, 2006). Dat geschiedt door 'mechanismen' bloot te leggen. Beleidsevaluatoren definiëren mechanismen verschillend (Lemire e.a., 2020), maar gaan er doorgaans van uit dat deze bestaan uit verborgen cognitieve en gedragsmechanismen (Astbury \& Leeuw, 2010). Inzicht in werkende mechanismen vormt een goede basis voor het formuleren van geïnformeerde en gerichte onderzoeksvragen voor effectonderzoek, het interpreteren van (on)bedoelde effecten en het bijsturen van het systeem op specifieke onderdelen (Van der Knaap, 2010; Donaldson, 2007). Hoewel planevaluaties 
in het veiligheidsdomein niet vaak ex ante worden verricht, biedt een ex-postreconstructie van een beleidstheorie dezelfde voordelen als hiervoor geschetst (Astbury \& Leeuw, 2010).

\section{Data en methode}

\section{Planevaluatie}

Om de onderzoeksvraag te kunnen beantwoorden is een planevaluatie uitgevoerd van het systeem van Promoveren en Degraderen. Deze vorm van evaluatie wordt gebruikt om te beoordelen hoe beleid zijn doelstellingen bereikt, door de onderliggende beleidstheorie te onderzoeken (Rossi e.a., 2004). Dit vereist een reconstructie en evaluatie van de veronderstelde causale (sociale en gedrags)mechanismen, doelstellingen en verwachte effecten met betrekking tot de beoogde doelgroep (Leeuw, 2008). Het duiden van mechanismen als 'causaal' kan onterecht de suggestie wekken dat zij geïsoleerd en op een lineaire wijze een doel veroorzaken (bijv. Mayne, 2012). We spreken daarom in deze planevaluatie over de mate waarin mechanismen kunnen bijdragen aan een bepaald (sub)doel. Wel hanteren we, in lijn met eerdere evaluaties (Van Noije \& Wittebrood, 2008; Bosma, 2017 en de gebruikte taal in de bestudeerde documenten, de term 'causale' veronderstellingen om de veronderstelde mechanismen te duiden.

Het reconstrueren en evalueren van de beleidstheorie van justitiële interventies wordt in Nederland steeds gebruikelijker (zie bijv. Van Noije \& Wittebrood, 2008; Bosma, 2016). Leeuw (2003) heeft een beleidswetenschappelijke methode ontwikkeld om deze reconstructie uit te voeren (zie ook Klein Haarhuis \& Leeuw, 2004; Ehren e.a., 2005). De methode legt de doelstellingen en veronderstelde causale mechanismen van een interventie systematisch bloot en maakt het mogelijk om te beoordelen in hoeverre zij gebaseerd zijn op wetenschappelijke kennis (Van der Knaap \& Schilder, 2004). De chronologische stappen van deze benadering zijn: (1) identificeer middelen; (2) koppel middelen aan geïdentificeerde doelstellingen; (3) herschrijf middelen-doelstellingenrelaties in 'als, dan'-statements; (4) identificeer causale mechanismen die deze relaties onderbouwen; (5) integreer middelen en doelstellingen en veronderstelde onderliggende causale mechanismen in een (logisch) theoretisch model; en (6) bepaal de plausibiliteit van het theoretisch model. Deze benadering is in deze evaluatie gevolgd, omdat deze goed bruikbaar is voor beleid waarvoor schriftelijke informatie voorhanden is (Leeuw, 2003). De plausibiliteit is bepaald door de congruentie van de beleidstheorie met relevant empirisch onderzoek en theorie te beoordelen. De centrale onderzoeksvraag van deze bijdrage is: Wat is de beleidstheorie van het systeem van Promoveren en Degraderen zoals dat in 2014 is ingevoerd? Deze overkoepelende vraag is, aan de hand van de beleidswetenschappelijke benadering, uitgesplitst in de volgende vijf subvragen:

1 Wat is de doelgroep van het systeem van Promoveren en Degraderen?

2 Wat zijn de (sub)doelen en middelen van het systeem van Promoveren en Degraderen?

3 Wat zijn causale veronderstellingen van het systeem van Promoveren en Degraderen? 
4 Is de beleidstheorie van het systeem van Promoveren en Degraderen in lijn met wetenschappelijk onderzoek?

5 In hoeverre is de beleidstheorie van het systeem van Promoveren en Degraderen consistent en coherent?

\section{Dataverzameling}

Voor het in kaart brengen van de beleidstheorie zijn documenten gezocht via de wetenschappelijke zoekmachines Web of Science en Google Scholar, evenals verschillende websites: zoek.officiëlebekendmakingen.nl, tweedekamer.nl, eerstekamer.nl, commissievantoezicht.nl, inspectie-jenv.nl en puc.overheid.nl/rsj. De gebruikte zoektermen zijn: 'promo*', 'degrad*', 'stimuleren', 'ontmoedigen', 'dagprogramma', 'straf', 'belon*' en een combinatie van deze termen. Documenten werden verzameld van januari tot maart 2020. Er werden geen datum- of taalbeperkingen toegepast. Dit leverde een groot aantal zoekresultaten op. De resultaten werden gescreend aan de hand van vooraf opgestelde inclusiecriteria:

1 bevat relevante informatie over de beoogde doelgroep, middelen, (sub)doelen en/of (de onderbouwing van) causale veronderstellingen van het systeem; en

2 daterend van vóór 1 maart 2014.

Er werden enkel stukken van vóór de implementatie van het systeem geselecteerd omdat de beleidstheorie van het oorspronkelijke systeem het onderwerp van studie was. Uiteindelijk voldeden 98 documenten aan het eerste inclusiecriterium. Deze documenten kunnen worden gecategoriseerd als (toelichtingen op) wetten en regelingen (2), Kamerbrieven en verslagen van politieke vergaderingen van de Eerste Kamer (2) en Tweede Kamer (41), rapporten van de Inspectie van Justitie en Veiligheid (5), de Dienst Justitiële Inrichtingen (DJI) (3), het Wetenschappelijk Onderzoek- en Documentatiecentrum (3), wetenschappelijke artikelen (11), scripties (4), huisregels van gevangenissen (1), onderzoeksrapporten van onafhankelijke onderzoekbureaus (2), adviezen over overheidsbeleid zoals van de Raad voor Strafrechtstoepassing en Jeugdbescherming (RSJ) en de Raad van State (RvS) (9), en jurisprudentie (15). Van deze documenten voldeden er twaalf aan de inclusiecriteria: de (toelichting op de) Regeling Selectie, Plaatsing en Overplaatsing van Gedetineerden (RSPOG) waarin het systeem van Promoveren en Degraderen is beschreven, de handleiding voor gedragsbeoordeling bij het systeem en tien Kamerbrieven en verslagen van politieke vergaderingen van de Tweede Kamer (zie bijlage). De resterende 86 documenten zijn niet gebruikt om de beleidstheorie te reconstrueren. Indien zij referenties bevatten naar relevant wetenschappelijk onderzoek, zijn die referenties wel nagelezen ten bate van de uitgevoerde wetenschappelijke toets. De wetenschappelijke toets is echter primair gestoeld op internationale literatuur afkomstig uit een systematische literatuurreview naar beloningssystemen in detentie; een studie die eveneens onderdeel is van het lopende dissertatietraject. Hiertoe zijn de databases Web of Science, PsychInfo, Criminal Justice Abstracts, ProQuest en Google Scholar in maart 2021 geraadpleegd. De zoektermen gebruikt in die literatuurreview zijn: ('contingency management' OR 'response cost*' OR 'positiv* reinforc*' OR 'negativ* reinforc*' OR incentiv* OR privileg* OR reward* OR 'operant* condition*' OR 'radical behav*' OR 'behav* modif*') AND ('correctional institution*' OR 'correctional facilit”' OR penitentiar* OR *pri- 
son* OR jail* OR incarc*) NOT ('prisoner dilemma*' OR 'prisoners dilemma*' OR 'prisoner's dilemma*' OR 'prisoners' dilemma*').

In de ontwikkelingsfase van het systeem zijn er onafhankelijke adviezen uitgebracht ten aanzien van de inrichting van het systeem (Plaisier \& Van Ditzhuijzen, 2009; RSJ, 2012; 2013a; 2013b). Het systeem van Promoveren en Degraderen zou naar eigen schrijven (Van Gent, 2013) in belangrijke mate gebaseerd zijn op het onafhankelijke advies over het stimuleren en ontmoedigen van gedetineerden, dat een uitgebreide literatuuranalyse bevat (Plaisier \& Van Ditzhuijzen, 2009). Het is echter niet geheel duidelijk in welke mate de beleidstheorie is gebaseerd op dit advies. Om die reden wordt in de analyse waar mogelijk aangegeven waar de beleidstheorie afwijkt van de adviezen.

In lijn met eerdere evaluaties van veiligheidsbeleid (Van Noije \& Wittebrood, 2008) zijn bij het identificeren van de middelen, doelen en veronderstelde causale mechanismen van het systeem van Promoveren en Degraderen uitspraken over doelgroep, middelen, doelstellingen en oorzakelijke relaties nauwkeurig onderzocht, door te zoeken naar specifieke woorden zoals 'doel', 'pijler', 'gericht op ...', 'beoogd', 'waardoor', 'leidt tot', enz. Doelstellingen, middelen en mechanismen zijn gecodeerd met behulp van kwalitatieve analysesoftware Atlas.ti. Vaak zijn veronderstelde causale mechanismen slechts impliciet beschreven in beleidsdocumenten (Van Noije \& Wittebrood, 2008). Deze studie was erop gericht zowel impliciete als expliciete doelstellingen, middelen en veronderstelde causale mechanismen in kaart te brengen. Impliciete aannames uit de documenten werden alleen meegenomen als de omringende tekst voldoende informatie bevatte om logischerwijs tot deze conclusie te komen. ${ }^{11}$ Indien een uitspraak over een van de onderdelen van de beleidstheorie werd genoemd in een document, maar deze niet werd herhaald in documenten van latere datum, is een inconsistentie geconstateerd. Indien een uitspraak in andere documenten werd weersproken, werd weerlegd, of de onderlinge samenhang onduidelijk was, is een incoherentie geconstateerd.

\section{Resultaten}

\section{Doelgroep}

De eerste vraag die we beantwoorden, is: wat is de doelgroep van het systeem van Promoveren en Degraderen? Het antwoord op deze vraag is schematisch weergegeven in figuur 1. Deze figuur laat zien dat het doel is dat bij binnenkomst in detentie de meeste gedetineerden automatisch in het Basisprogramma worden geplaatst, waarin zij ten minste zes weken verblijven. Veroordeelden die zich vrijwillig bij justitie melden om hun gevangenisstraf te ondergaan ('zelfmelders'), worden beoogd te starten in het Plusprogramma. ${ }^{12}$ Beslissingen tot promoveren of degra-

11 Om te controleren of de getrokken conclusies correct zijn, zijn aanvullende interviews gehouden met een voormalig beleidsadviseur van het Ministerie van Veiligheid en Justitie en een wetenschappelijk beleidsonderzoeker die bij de ontwikkeling van het systeem was betrokken. Het doel van deze interviews was het opvragen van (gemiste) relevante documentatie, evenals het verkrijgen van inzicht in de ontwikkeling van het systeem. 
deren worden in principe eens per zes weken genomen. Als gedetineerden minder dan zes weken gedetineerd zijn, zouden zij in de regel dus hun hele detentieduur in hetzelfde programma moeten verblijven.

De beleidstheorie beoogt dat het Plusprogramma enkel wordt aangeboden in reguliere gevangenisregimes, wat betekent dat andere regimes standaard een Basisprogramma of aangepast dagprogramma aanbieden (zie figuur 1). Daarnaast wordt beoogd dat gedetineerden in voorarrest of preventieve hechtenis ook deelnemen aan het systeem van Promoveren en Degraderen, maar omdat huizen van bewaring feitelijk geen Plusprogramma kennen, zullen zij bij gewenst (groen) gedrag pas beloningen ontvangen wanneer zij - indien veroordeeld - doorstromen naar een regulier gevangenisregime. Strafrechtelijk gedetineerde vreemdelingen (zowel preventief gehecht als veroordeeld) zouden ook moeten kunnen deelnemen aan het systeem, al zijn de gedragsregels waar zij zich aan moeten houden niet gericht op rehabilitatie maar op terugkeer naar land van herkomst. ${ }^{13} \mathrm{Zij}$ kunnen de facto evenmin promoveren als zij in huizen van bewaring verblijven.

Bovendien streeft het systeem na dat een aantal groepen gedetineerden van rechtswege permanent in het Basisprogramma verblijft, omdat meer vrijheid zich niet verhoudt tot de aard van hun detentie. Dat geldt voor gedetineerden op een uitgebreid beveiligde inrichting of afdeling (UBI), een extra beveiligde inrichting (EBI) en een terroristenafdeling (TA) (art. 1e aanhef en onder c RSPOG). Daarnaast wordt beoogd dat bepaalde groepen gedetineerden bij voorbaat permanent algeheel uitgesloten worden van deelname (zie figuur 1). Zij dienen een eigen dagprogramma te volgen. Een van de redenen voor het uitsluiten van deze groepen gedetineerden ('niet-kunners') is de veronderstelling dat zij psychisch niet capabel genoeg zijn om deel te nemen. De beleidstheorie neemt aan dat gedetineerden die in forensische ziekenhuizen of psychiatrische regimes worden geplaatst, niet in staat zijn om groen gedrag te vertonen als gevolg van stoornissen, zoals een verstandelijke beperking of een ernstige geestesziekte (waaronder ernstige verslavingsproblemen). Niet-kunners voor wie zorg en ondersteuning op reguliere afdelingen toereikend zijn, zouden wel deel moeten kunnen nemen aan het systeem (Van Gent, 2013). Beoogd wordt dat het gedrag van deze niet-kunners minder streng beoordeeld wordt. Als zij gemotiveerd zijn om te veranderen (d.w.z. deelnemen aan de Reflector en Kies voor Verandering), zouden zij ook met het vertonen van oranje gedrag op het onderdeel 'Zorg en begeleiding' in aanmerking kunnen komen voor het Plusprogramma (art. 1d lid 4 RSPOG). ${ }^{14}$

\section{Middelen en (sub)doelen}

De tweede onderzoeksvraag die we beantwoorden bij het reconstrueren van de beleidstheorie luidt: wat zijn de (sub)doelen en middelen van het systeem van Promoveren en Degraderen? Het antwoord hierop is weergegeven in figuur 2. Bestudering van de twaalf beleidsdocumenten laat zien dat drie middelen ingezet kunnen worden om de doelen te bereiken, te weten: straffen, beloningen en motiverende bejegening. De straffen en beloningen van het systeem van Promoveren en 
Degraderen zijn in de inleiding al beschreven. Straffen en beloningen zijn identiek, aangezien de straf feitelijk het wegnemen van beloningen betekent. Beloningen worden doorgaans als totaalpakket toegekend of weggenomen. Motiverende bejegening is in de kern een gespreksmethodiek gebaseerd op respect, menswaardigheid, vertrouwen, ondersteuning en interactie, en is erop gericht gedetineerden te helpen nadenken over hun gedrag en hun bereidheid tot verandering te stimuleren (Van Gent, 2013).

In de beleidsdocumenten konden tien (sub)doelen worden geïdentificeerd, die op drie niveaus kunnen worden onderscheiden: micro-, meso- en macroniveau. Op micro- of individueel niveau zijn de doelstellingen het vergroten van de motivatie om te veranderen (extrinsiek en intrinsiek), ${ }^{15}$ gewenst gedrag (Van Gent, 2013), ${ }^{16}$ het stimuleren van de eigen verantwoordelijkheid (responsabilisering), het beperken van detentieschade en reductie van recidive. Recidivereductie is echter alleen als een indirecte doelstelling beschreven, nooit als een directe doelstelling (Van Gent, 2013). Responsabilisering van gedetineerden houdt hier in dat zij zelf verantwoordelijk worden gehouden voor het verloop van hun detentie, in plaats van de overheid. Gedetineerden mogen tot op zekere hoogte zelf kiezen of zij zich 'verantwoordelijk' gedragen (groen) of niet (rood), maar moeten ook de consequenties van die gedragskeuzes ondergaan. Als zij zich gewenst gedragen en motivatie tonen, worden zij beloond. Zo niet, dan worden de beloningen hun (weer) ontzegd. Op meso- of organisatie-/politiek niveau konden drie doelen worden geïdentificeerd: het bevorderen van de orde en veiligheid in de gevangenis (Van Gent, 2013), efficiënte inzet van middelen (Van Gent, 2013) ${ }^{17}$ en het helpen beslissen over detentiefasering (Van Gent, 2013). ${ }^{18}$ Op twee punten willen wij nadere toelichting geven. Allereerst bleek uit de beleidstheorie dat het handhaven van de orde en veiligheid binnen de gevangenissen een hogere prioriteit heeft dan het geven van (extra) verantwoordelijkheden aan gedetineerden (Van Gent, 2013). Orde en veiligheid wordt van belang geacht voor het verschaffen van een veilig werk- en leefklimaat. Als tweede is het efficiënt inzetten van middelen herkenbaar in het principe 'niet investeren, tenzij .... ${ }^{19}$ Dit principe houdt in dat er enkel geld wordt gestoken in (d.w.z. beloningen toegekend worden aan) gedetineerden die gemotiveerd en kansrijk zijn om hun gedrag te beteren ${ }^{20}$ en 'dus' die investering verdienen (Van Gent, 2013). In de bestudeerde beleidsdocumenten is geen ander argument gevonden voor de splitsing dan dit economische argument. Als laatste wordt beoogd om gedetineerden verantwoord toe te leiden naar elektronische detentie en vervroegde invrijheidstelling, mede op grond van inzicht in hun gedrag en motivatie. Op macro- of maatschappelijk niveau is het vergroten van de maatschappelijke veiligheid als doelstelling beschreven. ${ }^{21}$ 


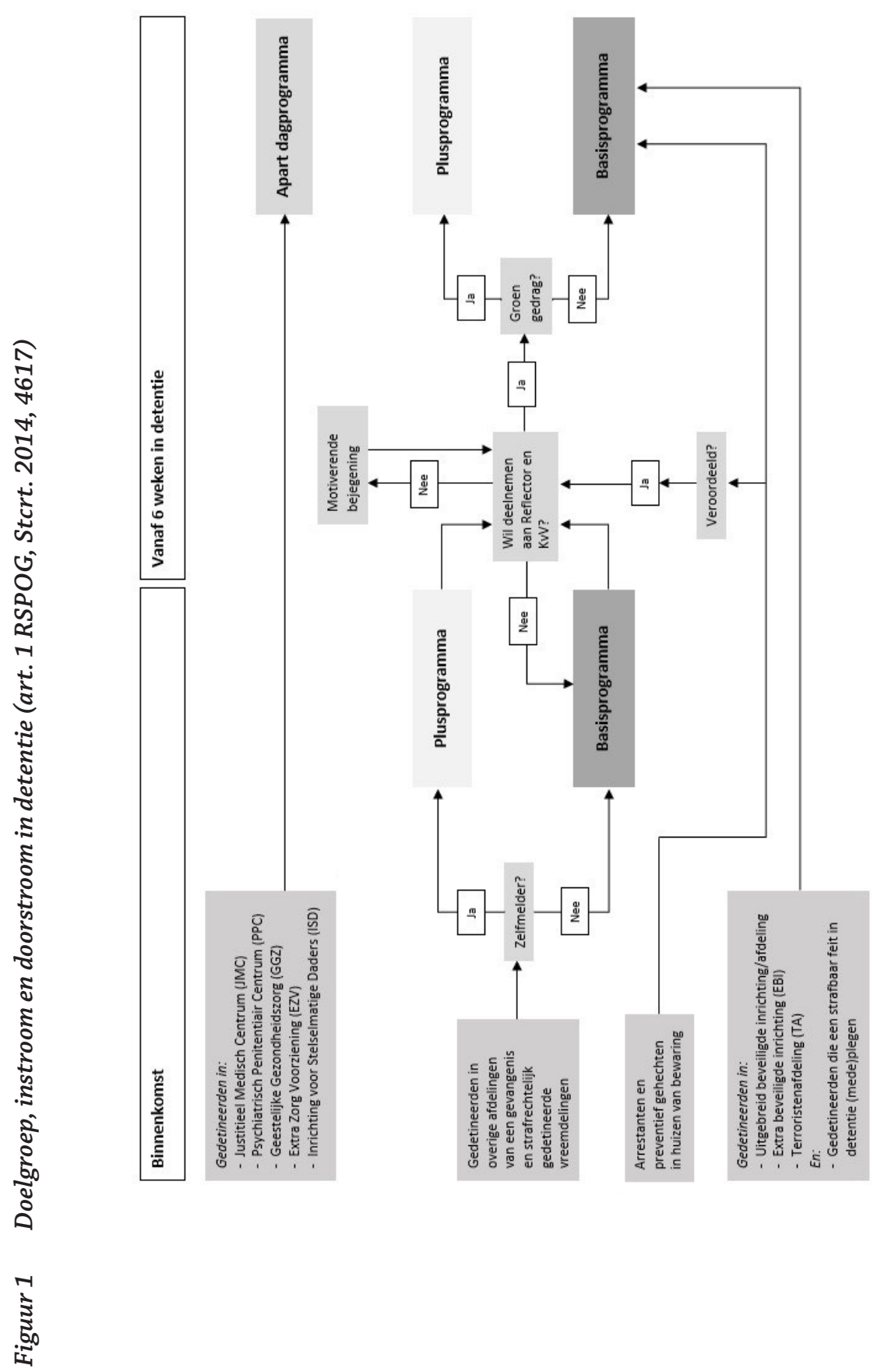




\section{Causale veronderstellingen}

Hiervoor hebben we de veronderstelde doel-middelrelaties ontrafeld. Daar liggen ook causale veronderstellingen aan ten grondslag, die we nu in kaart brengen. Daarmee beantwoorden we de derde onderzoeksvraag: wat zijn de causale veronderstellingen van het systeem van Promoveren en Degraderen? Bestudering van de twaalf beleidsdocumenten laat zien dat er 24 veronderstelde causale mechanismen worden vermeld. Deze mechanismen zijn aangeduid met pijlen in figuur 2. In de bestudeerde documenten worden drie causale ketens het meest frequent en uitvoerig besproken. Zij beslaan alle middelen, zes van de tien (sub)doelen, en lijken de meest fundamentele causale veronderstellingen te bevatten, op voornamelijk microniveau. Om die redenen worden zij hierna besproken. De eerste keten raakt aan de principes van operante conditionering. De tweede keten gaat in op de rol van het stimuleren en nemen van verantwoordelijkheid door gedetineerden. De derde keten richt zich op motiverende bejegening, hetgeen als onmisbaar werd geacht voor de werking van het systeem (Van Gent, 2013). Omdat het systeem in belangrijke mate gebaseerd zou zijn op het advies van Plaisier en Van Ditzhuijzen (2009), zijn ook onderbouwingen van de causale veronderstellingen weergegeven die in dit advies zijn aangegeven.

1. Causale keten 1: Beloningen (pijl 2) + Straffen (pijl 6) $\rightarrow$ Gewenst gedrag (pijl 17) $\rightarrow$ Orde en veiligheid in de inrichting

De eerste veronderstelling in deze keten is dat beloningen en straffen bijdragen aan gewenst gedrag in de inrichting. Beloningen en straffen worden in veel beleidsdocumenten in één adem genoemd, ook als het gaat om beoogde effecten (Van Gent, 2013). Om die reden staan zij gezamenlijk opgenomen in deze causale keten. De veronderstelling dat een combinatie van beloningen en (milde) straffen een positief en duurzaam effect sorteert op gedragsverandering, staat beschreven in de handleiding bij het systeem (Van Gent, 2013). De handleiding baseert zich daarbij expliciet op een literatuuronderzoek uit het advies van Plaisier en Van Ditzhuijzen (2009), maar onderbouwt niet waarom de geselecteerde beloningen en straffen zouden bijdragen aan het naleven van de gedragscriteria. Het aangehaalde literatuuronderzoek includeert inzichten uit algemene leertheorieën en empirisch onderzoek over conditionering (Skinner, 1938; Anderson \& Skinner, 1995), handhaving en regelnaleving in het publieke domein (Kazdin, 2001; Van der Pligt e.a., 2007), Token Economies ${ }^{22}$ (Kazdin, 1982), evenals expertbijeenkomsten die ten bate van de ontwikkeling van de handleiding zijn gehouden. Uit deze bronnen volgt volgens de handleiding (Van Gent, 2013) ook dat het alléén straffen van ongewenst gedrag op lange termijn niet zal bijdragen aan regelnaleving. Wanneer de systematiek van beloningen en straffen wegvalt, zoals bij vrijlating, zouden de effecten snel kunnen afnemen.

De tweede veronderstelling in deze keten is dat gewenst gedrag bijdraagt aan orde en veiligheid in de inrichting. Onder orde en veiligheid in de inrichting wordt het naleven van regels en afspraken verstaan, waarmee een open en respectvol klimaat

22 Token Economy is een CM-systeem waarbij deelnemers tokens kunnen verdienen, die zij kunnen inwisselen voor beloningen naar hun gading. 
wordt gecreëerd. ${ }^{23}$ Regelnaleving, het honoreren van regels en afspraken, evenals respectvol omgaan met personeel zijn vervat in gedragscriteria voor gedetineerden (zie RSPOG). De verwachte kern van deze veronderstelling lijkt echter het minimaliseren van wangedrag te zijn (Plaisier \& Van Ditzhuijzen, 2009). Afname van wangedrag neemt volgens de beleidstheorie ook een voorname aanleiding van overplaatsingen weg (Van Gent, 2013). Zo zou gewenst gedrag direct moeten bijdragen aan orde en veiligheid in de inrichting.

2. Causale keten 2: Beloningen (pijl 1) $\rightarrow$ Stimuleren eigen verantwoordelijkheid (pijl 12) $\rightarrow$ Beperking detentieschade

De tweede keten veronderstelt allereerst dat beloningen bijdragen aan het stimuleren van de eigen verantwoordelijkheid. De beleidsdocumenten noemen niet waarop de beloningen zijn gebaseerd. De beloningen lijken impliciet te zijn afgeleid van disciplinaire maatregelen en gedragsnormen die al decennia in detentie worden gebruikt (zie Plaisier \& Van Ditzhuijzen, 2009). Het is echter onduidelijk waarom de beleidstheorie veronderstelt dat juist de geselecteerde beloningen bij zullen dragen aan het stimuleren van het nemen van verantwoordelijkheid. De handleiding stelt dat de belonende waarde van een straf of beloning per individu kan verschillen en daarom individualisering tot op zekere hoogte van belang is (Van Gent, 2013). Die claim wordt gestaafd met een referentie aan correspondentie met orthopedagogen die kennis hebben van de doelgroep met een licht verstandelijke beperking (LVB). Gedragsdeskundigen gaven in de ontwikkelingsfase van het systeem aan dat het individualiseren van beloningen en straffen belangrijk is (vooral voor niet-kunners), omdat de belonende waarde van een straf of beloning per individu kan verschillen (Van Gent, 2013). Welke vorm en mate van individualisering bij zou kunnen dragen aan het stimuleren van de eigen verantwoordelijkheid, en waarom, noemen de beleidsdocumenten bovendien niet.

De tweede keten veronderstelt vervolgens dat het stimuleren van eigen verantwoordelijkheid bijdraagt aan beperking van detentieschade. ${ }^{24}$ De beleidsdocumenten leggen niet expliciet uit wat moet worden verstaan onder het 'stimuleren' van de 'eigen verantwoordelijkheid' van gedetineerden (zie ook RSJ, 2012). Impliciet wordt dit meer dan eens gelijkgesteld aan het verkrijgen van toegang tot plusactiviteiten en mogelijk voorwaardelijke invrijheidstelling (VI) door het vertonen van gewenst gedrag, in tegenstelling tot van rechtswege. ${ }^{25}$ Volgens het advies van Plaisier en Van Ditzhuijzen $(2009,8)$ kan detentieschade ontstaan door een vrijblijvend, onverschillig en normloos detentieklimaat, maar kan '(...) zelfstandigheid van gedetineerden en de mogelijkheid om zelf initiatieven te nemen' dat voorkomen. Naar dit deel van het advies wordt echter niet expliciet verwezen in de beleidsdocumenten, waar geen enkele onderbouwing van deze veronderstelling is gevonden. 
3. Causale keten 3: Motiverende bejegening (pijl 5) $\rightarrow$ Intrinsieke motivatie (pijl 22) $\rightarrow$ Recidivereductie

De derde keten veronderstelt allereerst dat motiverende bejegening bijdraagt aan intrinsieke motivatie. De beleidstheorie veronderstelt dat motiverende bejegening een positief zelfbeeld versterkt en hoop geeft, door principes van respect, menselijkheid, vertrouwen, steun en interactie in de bejegening van gedetineerden te hanteren. Hierdoor zou de intrinsieke motivatie van gedetineerden om hun gedrag te veranderen toenemen (Van Gent, 2013). Dit zou in lijn zijn met de zelfdeterminatietheorie (Deci \& Ryan, 1995; Ryan \& Deci, 2000).

De derde keten veronderstelt vervolgens dat intrinsieke motivatie bijdraagt aan recidivereductie. Deze veronderstelling wordt in de bestudeerde documenten indirect en meestal impliciet aangedragen. Intrinsieke motivatie zou tot gedragsverandering leiden, door meer deelname aan resocialisatieactiviteiten en gedragsinterventies te stimuleren, en zo indirect tot recidivereductie. Er wordt ook aangenomen dat gedetineerden met een LVB waarschijnlijk niet intrinsiek te motiveren zijn, maar wel extrinsiek (Van Gent, 2013).

\section{Wetenschappelijke onderbouwing}

Tot slot bestuderen we in hoeverre de veronderstellingen die onder het beleid liggen, gebaseerd zijn op resultaten van empirische studies. Ofwel, we beantwoorden de vierde onderzoeksvraag: is de beleidstheorie van het systeem van Promoveren en Degraderen in lijn met wetenschappelijk onderzoek? Om deze vraag te beantwoorden hebben we allereerst alle empirische studies die genoemd zijn in de bestudeerde beleidsdocumenten nagelezen, en beoordeeld of deze bronnen de causale veronderstellingen onderbouwen (ex tunc-toets). Daarnaast hebben we ook relevante empirische studies die na implementatie van het systeem in 2014 zijn gepubliceerd, meegenomen in de beoordeling van de wetenschappelijke onderbouwing (ex nunc-toets). In de afgelopen jaren is vooral meer kennis ontwikkeld over de responsiviteit en bejegening van gedetineerden met een LVB en zijn er aanvullende (kwalitatieve) inzichten in de effecten van het Britse IEP-programma. Hierna geven we per causale keten (zie hiervoor) weer of de beleidsveronderstellingen adequaat onderbouwd zijn. 


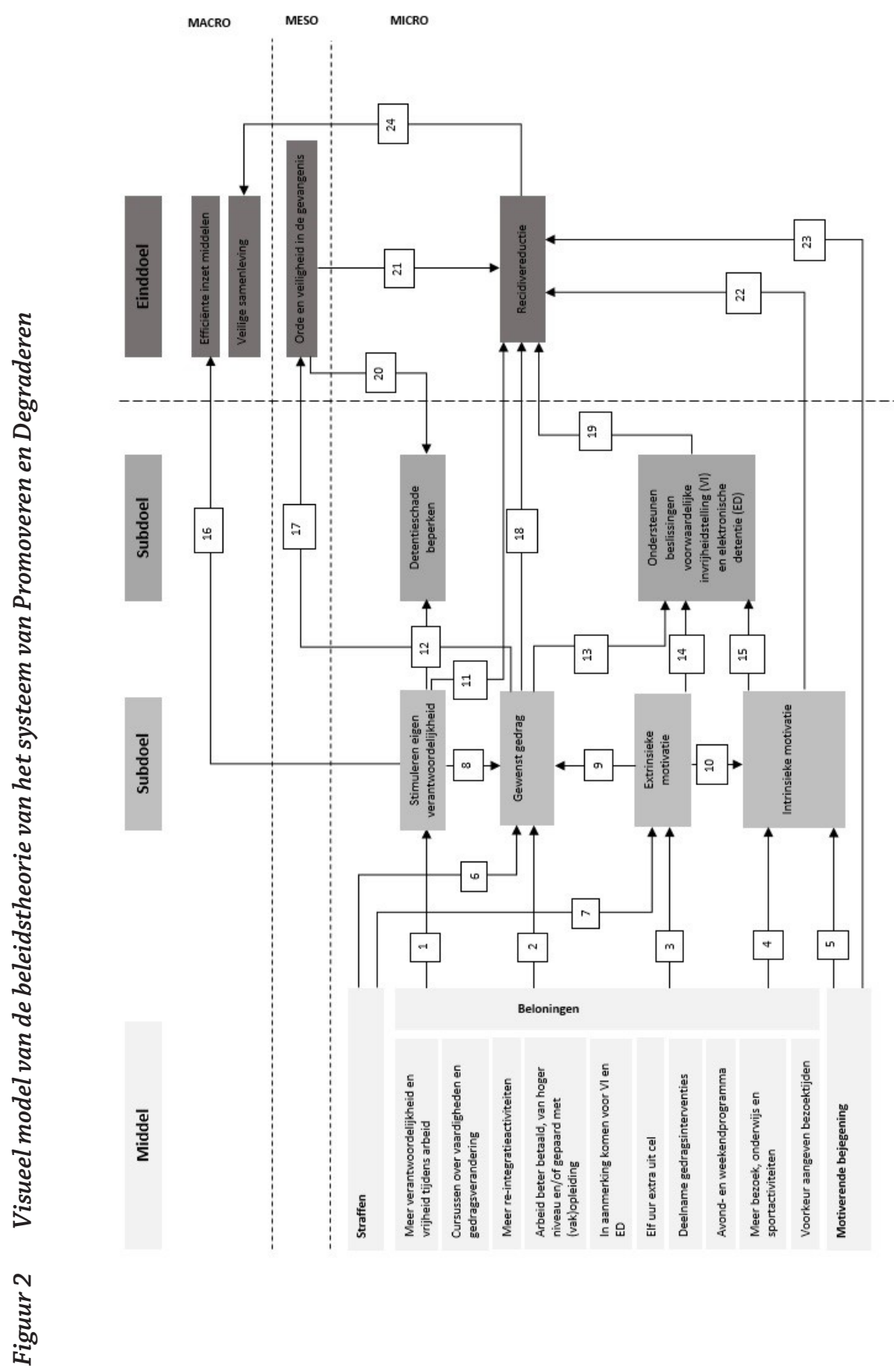


1. Causale keten 1: Beloningen (pijl 2) + Straffen (pijl 6) $\rightarrow$ Gewenst gedrag (pijl 17) $\rightarrow$ Orde en veiligheid in de inrichting

Er ontbreekt overtuigend empirisch bewijs dat deze veronderstelling opgaat voor gedetineerden. Empirisch onderzoek toont aan dat mensen verschillen in de ervaring en waardering van beloningen. Sommige gedetineerden die participeerden in het Britse IEP-programma hechtten veel belang aan bezoek (Booth, 2020; Khan, 2020), maar gedetineerden zonder sociaal netwerk niet (Khan, 2020). Wélke beloningen een individuele gedetineerde het meest waardevol vindt, behoeft meer empirisch onderzoek (Gendreau e.a., 2014). Individuele verschillen verklaren mogelijk waarom schaarse studies naar gedragsbeïnvloedingssystemen in gemêleerde detentiepopulaties gemengde effecten op regelnaleving laten zien (Liebling, 2008; Serin \& Hanby, 2009). Kwalitatief onderzoek naar IEP-participanten toont daarnaast aan dat arbitraire implementatie en uitvoering van een dergelijk systeem kan bijdragen aan gevoelens van angst, hulpeloosheid (Crewe, 2011) en onrechtvaardige behandeling onder gedetineerden (Liebling, 2008), wat regelnaleving mogelijk verder kan frustreren. De beleidsdocumenten refereren overigens op geen enkel punt naar (onderzoek naar) het IEP-programma. Het advies van Plaisier en Van Ditzhuijzen (2009) biedt algemene aanknopingspunten voor de effecten van (niet per definitie systematische) beloningen en straffen, in niet-gedetineerde doelgroepen. Literatuur die zich specifiek richt op systematische beloning en bestraffing in gevangenissen is onderbelicht in hun literatuurstudie. Studies die dateren van na de invoering van het systeem suggereren dat deze algemene inzichten zich slecht laten vertalen naar de Nederlandse detentiepopulatie, gezien haar bijzondere kenmerken, zoals beperkt verstandelijk vermogen en verslavingsproblematiek (De Jong e.a., 2016; Den Bak e.a., 2018), die gepaard gaan met uitzonderlijke omgevingskenmerken (een gedwongen, gesloten groepssetting).

Gewenst gedrag draagt bij aan orde en veiligheid in de inrichting. Het is plausibel dat wangedrag van de ene gedetineerde wangedrag van de andere in de hand werkt, waarmee de facto de orde en veiligheid in de inrichting wordt verstoord. Zo vonden Ellis en collega's (1974) dat gedetineerden die worden geplaatst in een gevangenis waar veel gewelddadige gedetineerden verblijven, een hogere kans hebben op het zelf vertonen van wangedrag. Het is ook aannemelijk dat overplaatsingen aanleiding kunnen zijn voor onrust en (gewelds)incidenten. Kigerl en Hamilton (2016 onderzochten overplaatsingen van bijna 6.000 Amerikaanse gedetineerden en vonden dat meerdere factoren bijdragen aan wangedrag volgend op overplaatsing. Voorbeelden van dergelijke factoren zijn mentale gezondheid, bezetting (drukte) en stabiliteit van de populatie in de nieuwe detentieomgeving, evenals kenmerken van de oude detentieomgeving. Het reduceren van overplaatsingen zou zo de orde en veiligheid in de inrichting ten goede komen. In hoeverre overplaatsingen op zich relateren aan een hogere kans op wangedrag is niet empirisch onderzocht. Op grond van deze empirische inzichten is het plausibel dat gewenst gedrag bijdraagt aan orde en veiligheid in de gevangenis, al ontbreekt empirische onderbouwing voor de Nederlandse situatie. 
2. Causale keten 2: Beloningen (pijl 1) $\rightarrow$ Stimuleren eigen verantwoordelijkheid (pijl 12) $\rightarrow$ Beperking detentieschade

Beloningen dragen bij aan stimuleren van eigen verantwoordelijkheid. Uit onderzoek onder gedetineerden vloeit geen overtuigend bewijs voort dat de veronderstelling, dat de geselecteerde beloningen onder de gestelde omstandigheden bijdragen aan het stimuleren van de eigen verantwoordelijkheid, ondersteunt. Op enkele punten druist deze veronderstelling zelfs in tegen empirische bevindingen die volgen uit onderzoek onder niet-gedetineerden. Studies naar regelnaleving onder niet-gedetineerden hebben vaak aangetoond dat beloningen effectief zijn als zij proportioneel zijn (Hodos \& Kalman, 1963; Cipani, 1990) en passen bij het individu en de omgeving waarin ze worden toegekend (Anderson \& Skinner, 1995; Van der Pligt e.a., 2007). Daarnaast dienen beloningen aantrekkelijk voor gedetineerden te zijn (Kazdin \& Bootzin, 1972). Er is echter niet geëxpliciteerd of en hoe individualisering van straffen en beloningen in de gevangenispraktijk wordt ingevuld, in een systeem dat standaardisatie van gedragsbeoordeling beoogt. ${ }^{26}$ Uit voornoemde literatuur over conditionering van dieren en compliance van mensen volgt bovendien dat hoe sneller de consequentie volgt op het gedrag, hoe beter het gedrag wordt aangeleerd of afgeleerd (Anderson \& Skinner, 1995; Van der Pligt e.a., 2007). Empirisch onderzoek onder delinquenten wijst eveneens uit dat hoe langer de tijd is tussen het vertonen van gewenst gedrag en de beloning, hoe groter de kans dat delinquenten zich verlaten op ongewenst gedrag (delay gratification) (Pierce e.a., 1972; Cipani, 1990) en de beloningen die dat gedrag voortbrengt - zelfs als die beloningen minder aantrekkelijk zijn dan voor gewenst gedrag (Arantes e.a., 2013; Hanoch e.a., 2013). Dat effect lijkt nog groter voor verslaafden (MacKillop e.a., 2011), al is onduidelijk of verslaving of persoonskenmerken (of een combinatie) dat effect veroorzaken. Voor straffen geldt echter het tegenovergestelde: mensen prefereren een klein verlies van beloningen op korte termijn doorgaans boven een geanticipeerd groter verlies op lange termijn (Holt e.a., 2008). Een mogelijke verklaring voor delay gratification is gebrekkige impulsbeheersing van gedetineerden (Meijers e.a., 2015). Dit suggereert dat de onmiddellijkheid van beloning gedragseffecten kan mediëren. De termijn van zes weken, waarna gedetineerden een promotie, degradatie of bestendiging van hun plek in een programma krijgen, voldoet niet aan de kwalificatie 'onmiddellijke' beloning. Aanvullend empirisch onderzoek naar werkzame beloningen en straffen onder gedetineerden is nodig om te bezien of deze bevindingen ook in Nederlandse context gelden.

Stimuleren van eigen verantwoordelijkheid draagt bij aan beperking van detentieschade. Zoals beschreven laten de beleidsmakers de duiding van deze begrippen over aan de lezer. Als ervan wordt uitgegaan dat onder het stimuleren van eigen verantwoordelijkheid het motiveren tot het vertonen van gewenst gedrag wordt verstaan, kan deze veronderstelling gedeeltelijk worden onderschreven met empirische en theoretische inzichten, afhankelijk van de beoogde doelgroep. De veronderstelling gaat op voor gedetineerden die het Plusprogramma bereiken, omdat daar (re-integratie)activiteiten worden aangeboden waarvan empirisch is bewezen dat zij doorgaans bijdragen aan vermindering van detentieschade door het vinden en behoud 
van huisvesting, werk en sociale relaties tijdens en na detentie (Boone \& Van Hattum, 2014). Die kennis was ten tijde van de ontwikkeling van het systeem bekend. Overtuigend empirisch bewijs dat deze veronderstelling opgaat voor Basis-gedetineerden was ten tijde van de invoering van het systeem niet voorhanden. Omdat het Basisprogramma minder re-integratieactiviteiten aanbiedt, kan worden betoogd dat de detentieschade van Basis-gedetineerden niet afneemt. Voornoemd kwalitatief onderzoek naar het (op het Nederlandse systeem lijkende) Britse IEP-programma toont zelfs indicaties dat hun detentieschade toe kan nemen, doordat gevoelens van angst, hulpeloosheid en onrechtvaardige behandeling andere (re-integratieve) interventies kunnen frustreren. Gevoelens van angst, hulpeloosheid en machteloosheid lijken geassocieerd te worden met een toename in relatieve autonomie binnen de gevangenismuren (Crewe, 2011; Shammas, 2014). Heersende rehabilitatiemodellen gaan er namelijk van uit dat onder meer een slechte therapeutische relatie, een gebrek aan externe hulpmiddelen, en cognitieve beperkingen de effectiviteit van justitiële interventies kunnen verstoren (Good Lives Model, Chambers e.a., 2008; Risk-Need-Responsivity Model (RNR-model), Bonta \& Andrews, 2010). Brits onderzoek suggereert dat een beperkte groep gedetineerden wel lijkt te profiteren van een systeem dat een toename in autonomie en verantwoordelijkheid genereert: de gedetineerden die al in grote mate zelfredzaam zijn (Crewe \& Levins, 2020). Het is echter onduidelijk of en hoe beloningen en straffen daaraan bijdragen.

3. Causale keten 3: Motiverende bejegening (pijl 5) $\rightarrow$ Intrinsieke motivatie (pijl 22) $\rightarrow$ Recidivereductie

Motiverende bejegening draagt bij aan intrinsieke motivatie. Er is enig empirisch en theoretisch bewijs dat deze veronderstelling ondersteunt, maar meer empirisch onderzoek is nodig. Het doel van motiverende bejegening is om veranderingsbereidheid te bevorderen (Miller \& Rose, 2009). Deze bejegening werd al voor de ontwikkeling van het systeem veelbelovend geacht voor justitiabelen (Ginsburg e.a., 2002). Recent onderzoek sluit daarbij aan (Stinson \& Clark, 2017). De principes van motiverende bejegening zijn namelijk congruent met zowel algemene leer- en motivatietheorieën als criminologische rehabilitatiemodellen. Zo stelt de algemene zelfdeterminatietheorie (Ryan \& Deci, 2000) dat autonomie, verbondenheid en competentie leiden tot intrinsieke motivatie voor (verandering van) gedrag en psychologische groei. Volgens deze theorie is het aannemelijk dat motiverende bejegening intrinsieke motivatie bevordert door self-efficacy te bevorderen (Ryan \& Deci, 2000). De claim dat deze veronderstelling aansluit bij de premissen van de zelfdeterminatietheorie (Van Gent, 2013) is dus plausibel. Helaas is deze theorie nog nauwelijks gevalideerd in gedetineerdenpopulaties (Van der Kaap-Deeder e.a., 2017). Ten tijde van de invoering van het systeem, en tot op de dag van vandaag, behoeft deze veronderstelling dus empirische validatie. Een andere aanwijzing voor de juistheid van deze veronderstelling laat zich vinden in heersende criminologische rehabilitatiemodellen. Bevordering van self-efficacy zou namelijk ook in lijn zijn met het Good Lives Model (Chambers e.a., 2008). Anderzijds zou motiverende bejegening ook de algemene responsiviteit van interventies kunnen verhogen, een belangrijke succesfactor voor gedragsverandering volgens het RNR-model (Bonta \& Andrews, 2010). 
Helaas ontbrak het op het moment van invoering van het systeem (en nog steeds) aan overtuigend empirisch bewijs dat motiverende bejegening positief uitwerkt op de intrinsieke motivatie van gedetineerden (McMurran, 2009). Dat geldt ook voor verminderd zelfredzame gedetineerden, zoals zij die met een LVB kampen (Panting e.a., 2018). De schaars beschikbare studies betreffen vooral casestudies (Mann \& Rollnick, 1996) en hanteren kleine samples (bijv. Anstiss e.a., 2011; Austin e.a., 2011; Ginsburg e.a., 2002). Uit de kleinschalige studies volgen wel aanwijzingen dat motiverende bejegening de zelfgerapporteerde veranderingsbereidheid van gedetineerden kan bevorderen (Austin e.a., 2011; Anstiss e.a., 2011). Aanvullend empirisch onderzoek onder gedetineerden is nodig om dit effect te valideren.

Intrinsieke motivatie draagt bij aan recidivereductie. Verscheidene theorieën ondersteunen deze veronderstelling, maar eenduidig empirisch bewijs is niet voorhanden. In algemene leertheorieën (Bandura, 1989), motivatietheorieën (Ryan \& Deci, 2000), evenals in heersende rehabilitatiemodellen (Bonta \& Andrews, 2010; Chambers e.a., 2008) wordt intrinsieke motivatie essentieel geacht voor blijvende gedragsverandering. Empirisch onderzoek in de gedetineerdenpopulatie naar de relatie tussen intrinsieke motivatie en recidivereductie in het kader van motiverende bejegening is beperkt. Eén kleinschalige studie naar motiverende bejegening gericht op verscheidene criminogene factoren liet een recidivereductie van 21 procent zien ten opzichte van een controlegroep (Anstiss e.a., 2011). Het gebruik van motiverende bejegening onder reclassanten toont ook veelbelovende effecten op recidive (Lin, 2018). Er zijn gemengde resultaten betreffende de relatie tussen motiverende bejegening en een reductie in middelengebruik (McMurran, 2009; Clair-Michaud e.a., 2016). Empirisch psychologisch onderzoek onder niet-gedetineerden toont aan dat motivatie (intrinsiek of extrinsiek) niet voldoende is om zelfstandig gedragsverandering te realiseren, wanneer cognitieve beperkingen of een gedragsbeperkende omgeving dit in de weg staan (Zimmermann \& Schunk, 2008). 'Willen' staat dus niet gelijk aan 'doen': ook individuele en omgevingskenmerken moeten gunstig zijn om gedrag te kunnen veranderen.

\section{Beleidsconsistentie en coherentie}

Tot slot wordt in deze paragraaf uiteengezet hoe consistent en coherent de beleidstheorie is. Drie punten vallen op met betrekking tot de consistentie van de beleidstheorie. Een incoherentie valt op ten opzichte van het onafhankelijke advies waarop het systeem in belangrijke mate zou zijn gebaseerd (Plaisier \& Van Ditzhuijzen, 2009). Ten eerste, in de uiteindelijke handleiding bij het toetsingskader van het systeem is het bevorderen van de orde en veiligheid in de inrichting beschreven als een verwacht neveneffect, maar niet als een primair doel (Van Gent, 2013). In eerdere beleidsdocumenten werd dit wel uitgelegd als een beoogde doelstelling van het systeem. ${ }^{27}$

Ten tweede bleek dat het beperken van detentieschade enkel expliciet als doelstelling van het systeem werd beschreven in oudere documenten die stammen uit de ontwikkelingsfase van het systeem, ${ }^{28}$ maar niet in meer recente beleidsdocumen- 
ten. Het is dan ook onduidelijk of het beperken van detentieschade (nog) een doelstelling was ten tijde van de implementatie van het systeem.

Ten derde, de opstellers van het advies stellen dat de causale veronderstellingen van een nieuw gedragsbeïnvloedingssysteem, die zich niet of beperkt empirisch hebben bewezen in detentiecontext, op kleine schaal in een pilot getest dienen te worden onder gedetineerden, alvorens het systeem grootschalig toe te passen (Plaisier \& Van Ditzhuijzen, 2009). Uit de beleidsdocumenten blijkt niet dat hieraan gehoor is gegeven.

Ten vierde wordt in het advies op grond van literatuuronderzoek gesteld dat het belonen van gewenst gedrag effectiever werkt voor gedragsverandering dan het straffen van ongewenst gedrag. Daarom wordt een mix van beloningen en milde straffen voorgesteld in de benadering van gedetineerden, waarbij ongewenst gedrag primair genegeerd dient te worden (Plaisier \& Van Ditzhuijzen, 2009). In de uiteindelijke handleiding hangt de bestraffing van ongewenst gedrag (degradatie) daarentegen juist doorlopend in de lucht voor Plus-gedetineerden (Van Gent, 2013). Het recentelijke elimineren van de oranje gedragscategorie zou die focus op straffen mogelijk kunnen versterken. Beloning en bestraffing zijn zijden van dezelfde medaille. Mogelijk worden zij om die reden in beleidsdocumenten vaak als één interventie benoemd, ook met betrekking tot hun verwachte effectiviteit. Voor die - in vergelijking met de geadviseerde richtlijn - grote rol van straffen in de gedragsverandering van gedetineerden ontbreekt wetenschappelijke onderbouwing in de beleidstheorie. Er is geen motivering aangetroffen voor de afwijkingen ten opzichte van de geadviseerde richtlijn en diens wetenschappelijke onderbouwing.

\section{Conclusie en discussie: implicaties voor het beleid en de praktijk}

De centrale vraag van deze planevaluatie was: Wat is de beleidstheorie van het systeem van Promoveren en Degraderen zoals dat in 2014 is ingevoerd? Om antwoord te geven op deze vraag zijn met de beantwoording van afzonderlijke subvragen de doelgroep, middelen, (sub)doelen en causale veronderstellingen van het systeem in kaart gebracht, met behulp van een beleidswetenschappelijke benadering (Leeuw, 2003; Ehren e.a., 2005). Uit de bevindingen van deze planevaluatie volgen drie hoofdconclusies.

Allereerst omvat de beoogde doelgroep van het systeem van Promoveren en Degraderen de reguliere detentiepopulatie. Dit is gelijk aan het Britse IEP-programma (Liebling, 2008), maar steekt af tegen de veelal specifieke subpopulaties die zijn geïncludeerd in andere onderzoeken naar CM-systemen in gevangenissen (Serin \& Hanby, 2009). Op grond van de huidige empirische kennis wijst deze planevaluatie uit dat het systeem van Promoveren en Degraderen waarschijnlijk onvoldoende rekening houdt met de heterogeniteit van zijn beoogde doelgroep. Uit verkennend onderzoek volgt dat tot 45 procent van de gedetineerden een LVB heeft (Kaal, 2016). Hoewel de beleidstheorie rekenschap geeft van de beperkingen van sommige groepen gedetineerden, is onvoldoende duidelijk hoe daarmee rekening wordt gehouden. Het risico bestaat dat gedetineerden met een LVB te weinig responsief zijn voor een generiek systeem van belonen, straffen en motiverende bejegening. 
Eerder effectonderzoek toont aan dat CM-systemen in detentie niet onverdeeld succesvol zijn (Serin \& Hanby, 2009). Een discrepantie tussen wat het systeem vraagt en de capaciteit van een deel van de doelgroep zou de potentiële effectiviteit van het systeem kunnen ondermijnen, of mogelijk zelfs aversieve effecten hebben. Voorbeelden van zulke effecten zijn het verminderen van (intrinsieke) motivatie voor gedragsverandering, het niet naleven van regels en het verslechteren van contact met personeel en behandelaars wegens ervaren gebrek aan procedurele rechtvaardigheid (bijv. Crewe, 2011; Liebling, 2008). Uit recent onderzoek blijkt deze discrepantie tussen de gevraagde autonomie en wat gedetineerden met een LVB de facto kunnen opbrengen ook na hun vrijlating te bestaan en bij te dragen aan problemen op tal van levensgebieden en een verhoogde kans op recidive (Teeuwen e.a., 2020). Het is te verwachten dat deze discrepantie in de komende jaren aandacht zal krijgen. Zo wordt er al in toenemende mate onderzoek gedaan naar de zelfredzaamheid van gedetineerden met verstandelijke beperkingen (bijv. Kaal e.a., 2011; Molleman, 2014), hoe deze gedetineerden met een LVB binnen de gevangenismuren geïdentificeerd kunnen worden (Kaal, 2013), en hoe gevangenispersoneel met hun beperkingen en gedrag om kan gaan (Vrij \& Kaal, 2015. Ten slotte is het aannemelijk dat een (meer zelfredzaam) deel van de gedetineerdenpopulatie deze discrepantie niet ervaart en wel baat kan hebben bij dit systeem, zoals dat is gevonden in het Britse IEP-programma (Crewe \& Levins, 2020).

Daarnaast volgt uit de beleidstheorie dat het systeem van Promoveren en Degraderen gebruik maakt van drie middelen (straffen, beloningen en motiverende bejegening) om tien (sub)doelen te bereiken. De beloningen zijn voor een groot deel gelijk aan de materiële en sociale beloningen en activiteiten die doorgaans in CM-systemen worden gebruikt, zoals meer loon, meer bezoekmogelijkheden en meer re-integratieactiviteiten (Gendreau \& Listwan, 2018). De nadruk op straffen en beloningen illustreert de principes van operante conditionering waarmee $\mathrm{CM}$-systemen opereren (Gendreau e.a., 2014). De verwachte spanning tussen het systeem en het resocialisatiebeginsel wordt door deze planevaluatie nog explicieter. Resocialisatie is grotendeels afhankelijk gemaakt van het gedrag en de motivatie van gedetineerden (Boone \& Van Hattum, 2014), doordat beloningen inderdaad vaak resocialisatiedoeleinden lijken te dienen, zoals deelname aan specifieke re-integratieactiviteiten, gedragsinterventies en activiteiten (in voor resocialisatie belangrijke levensdomeinen, zoals opleiding en sociaal netwerk). Een deel van de (sub)doelen van het systeem van Promoveren en Degraderen is gelijk aan de doelen van het Britse IEP-programma, zoals responsabilisering van gedetineerden, regelnaleving en recidivereductie (Liebling, 2008). Het valt op dat responsabilisering een voornaam doel is van dit systeem, naast de meer historische doelen van handhaving van orde en veiligheid van de inrichting en het afleren van verslavingsgedrag (Kratcoski, 2017).

Tot slot illustreert deze planevaluatie dat de wetenschappelijke plausibiliteit van de belangrijkste causale ketens (hoe middelen tot doelen leiden) in de beleidstheorie van het systeem van Promoveren en Degraderen zeer uiteenlopend is. Van de 24 causale veronderstellingen zijn er zeven onderzocht in de vorm van drie causale ketens. Voor een aantal veronderstellingen ontbrak ten tijde van de invoering van het systeem (en nog steeds) overtuigend empirisch bewijs, zoals ten aanzien van de 
veronderstelling dat beloningen de eigen verantwoordelijkheid stimuleren. De veronderstellingen zijn op die punten te voorbarig en in de beleidsdocumenten beperkt onderbouwd, gelijk aan de conclusies over het Britse IEP-programma (Bosworth \& Liebling, 1995). Op andere punten zijn er wel theoretische aanwijzingen dat de veronderstellingen houdbaar zijn, zoals de veronderstelling dat intrinsieke motivatie kan leiden tot recidivereductie. Helaas ontbreekt het veelal aan empirisch onderzoek dat aantoont dat deze veronderstellingen ook opgaan voor personen in een detentieomgeving. Ten aanzien van deze punten kan dus gesteld worden dat zij ten tijde van implementatie van een te algemene en theoretische evidence base waren voorzien. En dat terwijl de Nederlandse regering al jaren inzet op verankering van detentiebeleid in wetenschappelijke kennis, en specifiek het systeem van Promoveren en Degraderen..$^{29}$ De afwezigheid van praktisch toepasbare kennis over effecten van systematische beloning in detentie mag ook het criminologische onderzoeksveld zich aanrekenen. Toch hoeft het ontbreken van overtuigend empirisch en/of theoretisch bewijs geen reden voor beleidsmakers te zijn om het kind met het badwater weg te gooien. Het startpunt dient in dat geval echter niet grootschalige toepassing te zijn, maar het kleinschalig doorlopen van de empirische cyclus en het toetsen van specifieke veronderstellingen. De beleidsdocumenten geven echter geen blijk van een dergelijke gefaseerde aanpak.

Afsluitend waren de beleidsdocumenten op vier punten niet consistent of coherent. Het door de tijd heen wijzigen van middelen en tot op zekere hoogte (sub) doelen kan de beleidstheorie aantasten en daarmee ook de verwachte effecten beïnvloeden. Daarvan is echter weinig rekenschap gegeven. De inzet van motiverende bejegening in detentie, al dan niet gepaard gaande met een systeem van belonen en straffen, lijkt bij juiste uitvoering recht te kunnen doen aan het overkoepelende beleidsdoel van een persoonsgerichte benadering. Hoewel meer empirisch onderzoek naar motiverende bejegening in detentie nodig is, zijn er eerste, veelbelovende aanwijzingen dat dit instrument kan bijdragen aan de veranderingsbereidheid van gedetineerden.

\section{Methodologische kanttekeningen en aanbevelingen}

Deze planevaluatie betrof de eerste systematische evaluatie van de beleidstheorie van het systeem van Promoveren en Degraderen in Nederlandse gevangenissen zoals dat in 2014 is geïmplementeerd. Enkele kanttekeningen zijn op zijn plaats. Voor de reconstructie van de beleidstheorie is gebruik gemaakt van openbare documenten. Mogelijk zijn bepaalde (beleids)documenten niet openbaar en zodoende onder de radar gebleven (publication bias). Er is echter geen concrete indicatie dat er fundamentele doelen, middelen of veronderstellingen zijn gemist. Een tweede kanttekening betreft de selectie van documentatie. Aangezien het doel van deze bijdrage was om de originele beleidstheorie in kaart te brengen, zijn er geen documenten geïncludeerd die zijn verschenen na 1 maart 2014. In de jaren na diens implementatie is het systeem op bepaalde punten aangepast, zoals het schrappen van de oranje gedragscategorie en het veralgemeniseren van de overige gedragsregels. De besproken causale ketens lijken echter ongewijzigd. Een derde kantteke- 
ning is dat de wetenschappelijke toets slechts op een aantal fundamentele causale ketens van de beleidstheorie is toegepast. Daarmee blijft de wetenschappelijke plausibiliteit van de overige causale ketens ongewis. Deze reconstructie biedt wel duidelijke aanknopingspunten voor een uitgebreide toets. Tot slot is de wetenschappelijke plausibiliteit van de onderzochte causale ketens primair gebaseerd op systematisch literatuuronderzoek naar beloningssystemen in detentie. Daarbij zijn beloningen, en straffen, als categorieën behandeld. Er zijn geen mechanismen geidentificeerd voor de relatie tussen afzonderlijke beloningen of straffen en (sub) doelen op grond van bredere gedragsliteratuur. Beleidsevaluatoren staan die bredere en nog meer diepgaande werkwijze wel voor bij evaluatie van complexe systemen waarin meerdere mechanismen, vaak non-lineair en op meerdere niveaus, op elkaar in lijken te werken (zoals Pawson, 2013; Westhorp, 2012; 2013). Deze beperking kan tot gevolg hebben dat (indirect) relevante mechanismen die de geïdentificeerde veronderstellingen zouden kunnen verklaren, niet zijn achterhaald. Bovendien zou deze alternatieve benadering nog meer helderheid kunnen scheppen in de werking van mechanismen in de specifieke detentiecontext, waaronder bijvoorbeeld de institutionele setting, interpersoonlijke relaties tussen gedetineerden (en personeel) en individuele capaciteiten van gedetineerden worden verstaan (Pawson, 2013). Dat geldt ook voor differentiatie van werkende mechanismen naar verschillende doelgroepen. Zo wordt uit deze evaluatie bijvoorbeeld beperkt duidelijk in hoeverre procedurele rechtvaardigheid een mediërend effect zou kunnen hebben op de gedragsuitkomsten van verschillende doelgroepen in detentie. Overige gedragsliteratuur kan hiervoor mogelijk bruikbare hypothesen aanreiken. Hierin ligt een concreet aanknopingspunt voor vervolgonderzoek.

Een aantal bevindingen strekt tot aanbevelingen. Een logische eerste aanbeveling voor vervolgonderzoek betreft het toetsen van de overige causale ketens. Daarnaast is een proces- en effectevaluatie van het gehele systeem aan te raden. Deze planevaluatie heeft inzicht gegeven in het geheel aan veronderstellingen dat onder het systeem ligt. Dat vormt een goede basis voor het formuleren van geïnformeerde en gerichte onderzoeksvragen over effecten, het interpreteren van (on)bedoelde effecten, en specifieke handvatten voor revisie van de beleidstheorie (Van der Knaap, 2010). Een procesevaluatie kan meer inzicht bieden in de mate waarin het systeem conform de beleidstheorie en implementatietheorie is uitgevoerd, hetgeen mede afhankelijk is van de uitvoerende organisatie, de uitvoerders en politieke invloeden (Coolsma, 2008). Bovendien kan hiermee ook worden nagegaan in hoeverre de totstandkoming van eventuele (on)bedoelde effecten herleid kan worden tot afwijkingen in of van de implementatietheorie. Het Ministerie van Justitie en Veiligheid heeft een effectevaluatie van het systeem wel aangekondigd, ${ }^{30}$ maar het is onduidelijk wat deze interne evaluatie heeft opgeleverd. Beide evaluaties kunnen bijdragen aan een debat over de normatieve uitgangspunten van het systeem, bijvoorbeeld ten aanzien van wat van (gedetineerde) burgers verwacht mag worden. Toekomstige evaluaties van het systeem zouden oog moeten hebben voor twee aandachtspunten. 
Ten eerste de specifieke responsiviteit van niet-kunners in detentie, met name gedetineerden met een LVB. Hoewel een persoonsgerichte aanpak op papier leidend is, is het na reconstructie van de beleidstheorie nog onduidelijk hoe het systeem van Promoveren en Degraderen zijn middelen en (sub)doelen individualiseert. Criminologen en strafrechtjuristen hebben zich eerder kritisch uitgelaten over de normatieve uitgangspunten van het systeem, zoals de hoge mate van zelfredzaamheid die het van gedetineerden vraagt (bijv. Kelk, 2015; Van Ginneken, 2018). Vooral niet-kunners zouden die zelfredzaamheid mogelijk niet op kunnen brengen en daardoor weinig beloningen kunnen genieten en behulpzame tools voor hun re-integratie ontberen (Boone \& Uit Beijerse, 2018). Het is raadzaam om die (on)mogelijkheid nader te onderzoeken, met de groeiende wetenschappelijke kennis over de omvang, kenmerken en responsiviteit van deze groep justitiabelen in de hand. Een procesevaluatie kan deze onduidelijkheid wegnemen. De identificatie van gedetineerden met een LVB in detentie blijkt lastig (Kaal \& De Jong, 2017). Het is dan ook niet aannemelijk dat zij de extra zorg en aandacht krijgen die zij nodig hebben. Daarom is het ook raadzaam om in de praktijk meer aandacht te besteden aan de identificatie van niet-kunners onder gedetineerden, en het op maat maken van passende interventies (zoals beloningen, milde straffen en motiverende bejegening) door behandelaars. Betere identificatie vraagt allereerst om overkoepelend detentiebeleid, dat prioriteit toekent aan deze doelgroep en tijd, middelen en training van gevangenispersoneel regelt. De Inspectie Gezondheidszorg en Jeugd (2020) vond daarentegen dat in de meeste gevangenissen nog te weinig systematisch wordt ingezet op die identificatie.

Ten tweede dient vervolgonderzoek naar effecten oog te hebben voor onbedoelde aversieve effecten van een systeem van straffen en belonen. Zo leert recent kwalitatief onderzoek onder gedetineerden die participeren in het Britse IEP-programma dat (gebrekkige implementatie van) een dergelijk systeem ook kan leiden tot gevoelens van machteloosheid, angst, hulpeloosheid en onrechtvaardige behandeling. Mogelijk hangen die gevoelens samen met de manier en mate van gedragsbeoordeling door gevangenispersoneel (bijv. Crewe, 2011). Een procesevaluatie zou ook meer inzicht kunnen bieden in de werking en kwaliteit van dit beoordelingsproces. Tot slot laten de resultaten van deze planevaluatie zien dat de beleidstheorie van het systeem van Promoveren en Degraderen op enkele punten te voorbarig is. Dat geldt met name voor de aansluiting van het generieke systeem op individuele gedetineerden. In dit kader is het ook relevant nader te onderzoeken wat het elimineren van de oranje gedragscategorie voor gevolgen heeft voor met name niet-kunners, die mogelijk vaker in deze categorie vallen wegens hun beperkte verstandelijke vermogens. Toekomstig onderzoek kan meer licht werpen op de (onbedoelde) effecten van dit beloningssysteem op verschillende gedetineerde doelgroepen.

\section{Literatuur}

Anderson, E.A. \& Skinner, D.A. (1995). The components of family policy education. Journal of Family and Economic Issues, 16(1), 65-77. 
Anstiss, B., Polaschek, D.L. \& Wilson, M. (2011). A brief motivational interviewing intervention with prisoners: when you lead a horse to water, can it drink for itself? Psychology, Crime \& Law, 17(8), 689-710.

Arantes, J., Berg, M.E., Lawlor, D. \& Grace, R.C. (2013). Offenders have higher delay-discounting rates than non-offenders after controlling for differences in drug and alcohol abuse. Legal and Criminological Psychology, 18(2), 240-253.

Astbury, B. \& Leeuw, F.L. (2010). Unpacking black boxes: mechanisms and theory building in evaluation. American Journal of Evaluation, 31(3), 363-381.

Austin, K.P., Williams, M.W.M. \& Kilgour, G. (2011). The effectiveness of motivational interviewing with offenders: an outcome evaluation. New Zealand Journal of Psychology, 40(1), 55-67.

Bak, R.R. den, Popma, A., Nauta-Jansen, L.M.C., Nieuwbeerta, P., Marchena-Slot, A., Koenraadt, F. e.a. (2018). Psychosociale criminogene factoren en neurobiologische kenmerken van mannelijke gedetineerden in Caribisch Nederland. Leiden: Universiteit Leiden.

Bandura, A. (1989). Human agency in social cognitive theory. American Psychologist, 44(9), 1175-1184.

Bonta, J. \& Andrews, D. (2010). Viewing offender assessment and rehabilitation through the lens of the risk-need-responsivity model. In: F. McNeill, P. Raynor \& C. Trotter (eds.). Offender Supervision: New Directions in Theory, Research and Practice. Cullompton: Willan, 19-40.

Boone, M. \& Beijerse, J. uit (2018). Prisoner resettlement in the Netherlands: great initiatives for too few people. In: F. Dünkel, I. Pruin, A. Storgaard \& J. Weber (eds.). Prisoner Resettlement in Europe. London/New York: Routledge, 240-252.

Boone, M. \& Hattum, W. van (2014). Promoveren en degraderen van gedetineerden. Het wetsvoorstel elektronische detentie en de dreigende afschaffing van de detentiefasering. Nederlands Juristenblad, 89(31), 279-284.

Booth, N. (2020). Disconnected: Exploring provisions for mother-child telephone contact in female prisons serving England and Wales. Criminology \& Criminal Justice, 20(2), 150168.

Bosma, A. Q. (2017). Targeting recidivism: an evaluation study into the functioning and effectiveness of a prison-based treatment program (Doctoral dissertation, Leiden University).

Bosworth, M. \& Liebling, A. (1995). Incentives in Prison Regimes: A Review of the Literature. Cambridge: Institute of Criminology.

Burdon, W.M., Roll, J.M., Prendergast, M.L. \& Rawson, R.A. (2001). Drug courts and contingency management. Journal of Drug Issues, 31(1), 73-90.

Chambers, J.C., Eccleston, L., Day, A., Ward, T. \& Howells, K. (2008). Treatment readiness in violent offenders: the influence of cognitive factors on engagement in violence programs. Aggression and Violent Behavior, 13(4), 276-284.

Cipani, E. (1990). The communicative function hypothesis: an operant behavior perspective. Journal of Behavior Therapy and Experimental Psychiatry, 21(4), 239-247.

Clair-Michaud, M., Martin, R.A., Stein, L.A., Bassett, S., Lebeau, R. \& Golembeske, C. (2016). The impact of motivational interviewing on delinquent behaviors in incarcerated adolescents. Journal of Substance Abuse Treatment, 65, 13-19.

Coolsma, J.C. (2008). De uitvoering van overheidsbeleid. In: A. Hoogerwerf \& M. Herweijer (eds.). Overheidsbeleid. Een inleiding in de beleidswetenschap. Alphen aan den Rijn: Kluwer, 117-135.

Crewe, B. (2011). Soft power in prison: implications for staff-prisoner relationships, liberty and legitimacy. European Journal of Criminology, 8(6), 455-468.

Crewe, B. \& Levins, A. (2020). 'Tightness', recognition and penal power. Punishment \& Society, 13(5), 509-529.

Deci, E.L. \& Ryan, R.M. (1995). Human autonomy. In: M.H. Kernis (ed.). Efficacy, Agency, and Self-Esteem. Boston: Springer, 31-49. 
DJI (Dienst Justitiële Inrichtingen). (2020). Infographic Gevangeniswezen 2020. Geraadpleegd op www.dji.nl/themas-cijfers-en-publicaties/cijfers-en-publicaties/kerncijfersdji.aspx.

Donaldson, S.I. (2007). Program Theory-Driven Evaluation Science: Strategies and Applications. New York: Taylor \& Francis Group.

Donaldson, S.I. \& Lipsey, M.W. (2006). Roles for theory in contemporary evaluation practice: developing practical knowledge. In: I. Shaw, J.C. Greene \& M.M. Mark (eds.). The Handbook of Evaluation: Policies, Programs, and Practices. London/Thousand Oaks, CA: Sage, 56-75.

Drosterij, G. \& Peeters, R. (2011). De nieuwe burgerlijkheid: participatie als conformerende zelfredzaamheid. Beleid en Maatschappij, 38(4), 456-472.

Ehren, M.C., Leeuw, F.L. \& Scheerens, J. (2005). On the impact of the Dutch Educational Supervision Act: analyzing assumptions concerning the inspection of primary education. American Journal of Evaluation, 26(1), 60-76.

Ellis, D., Grasmick, H. G., \& Gilman, B. (1974). Violence in prisons: A sociological analysis. American Journal of Sociology, 80(1), 16-43.

Gendreau, P. \& Listwan, S.J. (2018). Contingency management programs in corrections: another panacea? Journal of Contemporary Criminal Justice, 34(1), 35-46.

Gendreau, P., Listwan, S.J., Kuhns, J.B. \& Exum, M.L. (2014). Making prisoners accountable: are contingency management programs the answer? Criminal Justice and Behavior, 41(9), 1079-1102.

Gent, L. van (2013). Handleiding Toetsingskader promoveren en degraderen. Den Haag: Dienst Justitiële Inrichtingen, Ministerie van Veiligheid en Justitie.

Ginneken, E.F.J.C. van (2018). Zelfredzaamheid in detentie. Kritische kanttekeningen bij het systeem van promoveren en degraderen. Proces, Tijdschrift voor Strafrechtspleging, 97(2), 113-129.

Ginsburg, J.I., Mann, R.E., Rotgers, F. \& Weekes, J.R. (2002). Motivational interviewing with criminal justice populations. Motivational Interviewing: Preparing People for Change, 2, 333-347.

Hanoch, Y., Rolison, J. \& Gummerum, M. (2013). Good things come to those who wait: time discounting differences between adult offenders and nonoffenders. Personality and Individual Differences, 54(1), 128-132.

Hodos, W. \& Kalman, G. (1963). Effects of increment size and reinforcer volume on progressive ratio performance. Journal of the Experimental Analysis of Behavior, 6(3), 387-392.

Holt, D.D., Green, L., Myerson, J. \& Estle, S.J. (2008). Preference reversals with losses. Psychonomic Bulletin \& Review, 15(1), 89-95.

Inspectie Gezondheidszorg en Jeugd (2020). Jaargesprekken over medische zorg in penitentiaire centra, detentiecentra en forensisch psychiatrische centra.

Jong, B.J. de, Willems, P.J.H. \& Torregrosa, L.D.R. (2016). Zelfredzaamheid in detentie. Evaluatie van de pilot Participerende Detentie \& Maatschappelijke Arbeid PI Nieuwersluis. Woerden: VanMontfoort.

Kaal, H.L. (2010). Beperkt en gevangen? De haalbaarheid van prevalentieonderzoek naar verstandelijke beperking in detentie (Cahier 2010-11). Den Haag: WODC.

Kaal, H.L. (2013). Evaluatie pilot 'Screenen voor LVB in het gevangeniswezen'. Leiden: Hogeschool Leiden.

Kaal, H. (2016). Prevalentie licht verstandelijke beperking in het justitiedomein. Leiden: Hogeschool Leiden.

Kaal, H.L. \& Jong, B.J. de (2017). Het signaleren en registreren van LVB in het justitiële domein: stof tot nadenken. Justitiële verkenningen, 43(6), 63-73.

Kaal, H.L., Negenman, A.M., Roeleveld, E. \& Embregts, P.J.C.M. (2011). De problematiek van gedetineerden met een lichte verstandelijke beperking in het gevangeniswezen. Tilburg: Universiteit van Tilburg. 
Kaap-Deeder, J. van der, Audenaert, E., Vandevelde, S., Soenens, B., Mastrigt, S. van, Mabbe, E. e.a. (2017). Choosing when choices are limited: the role of perceived afforded choice and autonomy in prisoners' well-being. Law and Human Behavior, 41(6), 567-578.

Kazdin, A.E. (1982). The token economy: a decade later. Journal of Applied Behavior Analysis, 15(3), 431-445.

Kazdin, A.E. (2001). Behavior Modification in Applied Settings. New York: Wadsworth.

Kazdin, A. \& Bootzin, R. (1972). The token economy: an evaluative review. Journal of Applied Behavior Analysis, 5, 343-372.

Kelk, C. (2015). Veranderende mensbeelden van gedetineerden. Justitiële verkenningen, 41(5), 81-96.

Khan, Z. (2016). An exploration of prisoners' perceptions of the Incentives and Earned Privileges' (IEP) scheme: the role of legitimacy. Prison Service Journal, 227, 11-16.

Khan, Z. (2020). A typology of prisoner compliance to the Incentives and Earned Privileges scheme: Theorising the neoliberal self and staff-prisoner relationships. Criminology \& Criminal Justice, $0(0), 1-18$.

Kigerl, A., \& Hamilton, Z. (2016). The impact of transfers between prisons on inmate misconduct: Testing importation, deprivation, and transfer theory models. The Prison Journal, 96(2), 232-257.

Klein Haarhuis, C. \& Leeuw, F.L. (2004). De reconstructie van programmatheorieën. Beschikbare methoden en een toepassing op het anti-corruptieprogramma van de Wereldbank. Justitiële verkenningen, 30(5), 11-30.

Knaap, P. van der (2010). Veiligheidsbeleid: onderbouwd en effectief? Tijdschrift voor Veiligheid, 9(1), 6-21.

Knaap, P. van der \& Schilder, A. (2004). Resultaatgericht sturen en evalueren. Nieuwe perspectieven op beleidsinstrumenten en beleidsevaluatie. Den Haag: Sdu Uitgevers.

Kratcoski, P.C. (2017). Correctional Counseling and Treatment. Cham: Springer.

Leeuw, F.L. (2003). Reconstructing program theories: methods available and problems to be solved. American Journal of Evaluation, 24(1), 5-20.

Leeuw, F.L. (2008). Gedragsmechanismen achter overheidsinterventies en rechtsregels (oratie Maastricht).

Lemire, S., Kwako, A., Nielsen, S. B., Christie, C. A., Donaldson, S. I., \& Leeuw, F. L. (2020). What is this thing called a mechanism? Findings from a review of realist evaluations. Causal Mechanisms in Program Evaluation. New Directions for Evaluation, 2020(167), 7386.

Liebling, A. (2008). Incentives and earned privileges revisited: fairness, discretion, and the quality of prison life. Journal of Scandinavian Studies in Criminology and Crime Prevention, 9(S1), 25-41.

Lin, J. (2018). Program evaluation in the context of supervision regime change: motivational interviewing in Colorado. Justice Quarterly, 35(5), 895-918.

MacKillop, J., Amlung, M.T., Few, L.R., Ray, L.A., Sweet, L.H. \& Munafò, M.R. (2011). Delayed reward discounting and addictive behavior: a meta-analysis. Psychopharmacology, 216(3), 305-321.

Mann, R.E. \& Rollnick, S. (1996). Motivational interviewing with a sex offender who believed he was innocent. Behavioural and Cognitive Psychotherapy, 14(2), 127-134.

Mayne, J. (2012). Contribution analysis: Coming of age?. Evaluation, 18(3), 270-280.

McMurran, M. (2009). Motivational interviewing with offenders: a systematic review. Legal and Criminological Psychology, 14(1), 83-100.

Meijers, J., Harte, J.M., Jonker, F.A. \& Meynen, G. (2015). Prison brain? Executive dysfunction in prisoners. Frontiers in Psychology, 6(43), 1-6.

Michigan Department of Corrections (2019). Policy directive. Segregation standards.

Miller, W.R. \& Rose, G.S. (2009). Toward a theory of motivational interviewing. American Psychologist, 64(6), 527-537. 
Molleman, T. (2014). Zelfredzaamheid gedetineerden. Den Haag: WODC.

Moriar, I., Motiuk, L.L. \& Keown, L.A. (2019). Characteristics of offenders participating in the Romanian Prison Service Credit System. European Journal of Crime, Criminal Law and Criminal Justice, 17(3), 242-259.

Noije, L. van \& Wittebrood, K. (2008). Sociale veiligheid ontsleuteld: veronderstelde en werkelijke effecten van veiligheidsbeleid. Den Haag: Sociaal en Cultureel Planbureau.

Panting, H., Swift, C., Goodman, W. \& Davis, C. (2018). Examining the utility of the Stages of Change model for working with offenders with learning disabilities. Journal of Intellectual Disabilities and Offending Behaviour, 9(2), 91-101.

Pawson, R. (2013). The Science of Evaluation: A Realist Manifesto. London: Sage Publications.

Pierce, C.H., Hanford, P.V. \& Zimmerman, J. (1972). Effects of different delay of reinforcement procedures on variable-interval responding 1, 2. Journal of the Experimental Analysis of Behavior, 18(1), 141-146.

Plaisier, J. \& Ditzhuijzen, J.V. van (2009). Stimuleren en ontmoedigen van gedetineerden. Amsterdam: Impact R\&D.

Pligt, J. van der, Koomen, W. \& Harreveld, F. van (2007). Bestraffen, belonen en beïnvloeden. Den Haag: Boom Juridische uitgevers.

Rossi, P.H., Lipsey, M.W. \& Freeman. H.E. (2004). Evaluation: A Systematic Approach. London: Sage.

RSJ (Raad voor Strafrechtstoepassing en Jeugdbescherming). (2012). Detentiefasering. Brief aan de Staatssecretaris van Veiligheid en Justitie.

RSJ (Raad voor Strafrechtstoepassing en Jeugdbescherming). (2013a). Advies gedetineerden met een licht verstandelijke beperking. Brief aan de Staatssecretaris van Veiligheid en Justitie.

RSJ (Raad voor Strafrechtstoepassing en Jeugdbescherming). (2013b). Advies wijziging Regeling SPOG in verband met promoveren en degraderen binnen het gevangeniswezen.

RSJ (Raad voor Strafrechtstoepassing en Jeugdbescherming). (2020). Promoveren en degraderen in detentie. Advies over een voorgenomen wijziging van regelgeving.

Ryan, R.M. \& Deci, E.L. (2000). Self-determination theory and the facilitation of intrinsic motivation, social development, and well-being. American Psychologist, 55(1), 68-78.

Schinkel, W. \& Houdt, F. van (2010). Besturen door vrijheid. Neoliberaal communitarisme en de verantwoordelijke burger. Bestuurskunde, (2), 12-21.

Serin, R.C. \& Hanby, L.J. (2009). Offender Incentives and Behavioural Management Strategies. Ottawa: Correctional Service of Canada.

Shammas, V.L. (2014). The pains of freedom: assessing the ambiguity of Scandinavian penal exceptionalism on Norway's Prison Island. Punishment \& Society, 16(1), 104-123.

Skinner, B.F. (1938). The Behavior of Organisms: An Experimental Analysis. New York: Appleton-Century.

Spiegler, M.D. \& Guevremont, D.C. (1993). Contemporary Behavior Therapy. Pacific Grove, CA: Brooks.

Stinson, J.D. \& Clark, M.D. (2017). Motivational Interviewing with Offenders: Engagement, Rehabilitation, and Reentry. London: Guilford Publications.

Teeuwen, M., Bruggeman, M., Dirkse, M. \& Malsch, M. (2020). Levenslange obstakels. Een levensloopstudie naar licht verstandelijk beperkten in het strafrecht en in de zorg. Amsterdam: Nederlands Studiecentrum Criminaliteit en Rechtshandhaving.

The Denver Post (2010, 14 November). Limon prison incentive programs keep inmates in check. Geraadpleegd op 20 mei 2020 via www.denverpost.com/2010/11/14/limonprison-incentive-programs-keep-inmates-in-check/.

The Guardian (2019, 12 July). Prisoners could get own keys as reward for good behaviour. Geraadpleegd op 21 mei 2020 via www.theguardian.com/society/2019/jul/12/ prisoners-may-get-perks-for-good-behaviour-in-rewards-based-reforms. 
Vrij, P. \& Kaal, H.L. (2015). Licht verstandelijke beperking in detentie. Een handreiking voor medewerkers van DJI over de omgang met gedetineerden met een LVB. Leiden: Hogeschool Leiden.

Westhorp, G. (2012). Using complexity-consistent theory for evaluating complex systems. Evaluation, 18(4), 405-420.

Westhorp, G. (2013). Developing complexity-consistent theory in a realist investigation. Evaluation, 19(4), 364-382.

Wooldredge, J. \& Smith, P. (eds.). (2018). The Oxford Handbook of Prisons and Imprisonment. Oxford: Oxford University Press.

Zimmerman, B.J. \& Schunk, D.H. (2008). An essential dimension of self-regulated learning. In: B.J. Zimmermann \& D.H. Schunk (eds.). Motivation and Self-Regulated Learning: Theory, Research, and Applications. New York: Taylor and Francis Group, 1-31.

\section{Bijlage De voor de planevaluatie bestudeerde beleidsdocumenten over het systeem van Promoveren en Degraderen}

Kamerstukken II 2005/06, 30300 VI, nr. 147. Vaststelling van de begrotingsstaten van het Ministerie van Justitie (VI) voor het jaar 2006. Brief aan de Minister van Justitie.

Kamerstukken II 2008/09, 24587, nr. 299. Justitiële Inrichtingen. Brief van de Minister en Staatssecretaris van Justitie.

Kamerstukken II 2008/09, 24587, nr. 310. Justitiële Inrichtingen. Brief van de Staatssecretaris van Justitie.

Kamerstukken II 2008/09, 24587, nr. 310, bijlage 1. Justitiële Inrichtingen. Brief van de Staatssecretaris van Justitie.

Kamerstukken II 2009/10, 24587, nr. 367. Brief aan de Staatssecretaris van Veiligheid en Justitie. Justitiële Inrichtingen.

Kamerstukken II 2010/11, 29270, nr. 52. Brief aan de Staatssecretaris van Veiligheid en Justitie. Reclasseringsbeleid.

Kamerstukken II 2010/11, 29270, nr. 61. Brief aan de Staatssecretaris van Veiligheid en Justitie. Reclasseringsbeleid.

Kamerstukken II 2012/13, 24587, nr. 490. Justitiële Inrichtingen. Brief van de Staatssecretaris van Veiligheid en Justitie.

Kamerstukken II 2013/14, 33745, nr. 7. Wijziging van de Penitentiaire beginselenwet en het Wetboek van Strafrecht in verband met de herijking van de wijze van de tenuitvoerlegging van vrijheidsbenemende sancties en de invoering van elektronische detentie. Nota naar aanleiding van het verslag.

Ministerie van Justitie (2009). Programma Modernisering Gevangeniswezen. Tweede voortgangsrapportage. Den Haag.

Staatscourant nr. 4617 (2014). Regeling en Toelichting van de Staatssecretaris van Veiligheid en Justitie van 10 februari 2014 houdende wijziging van de Regeling selectie, plaatsing en overplaatsing van gedetineerden in verband met de invoering van promoveren en degraderen van gedetineerden. 